\title{
Preferential Trade Agreements and the Law and Politics of GATT Article XXIV
}

\author{
Amin Alavi \\ Centre for International Business Law, Aarhus University, Denmark. \\ Email: amal@asb.dk \\ Received November 11 $1^{\text {th }}, 2010$; revised December $1^{\text {st }}, 2010$; accepted December $12^{\text {th }}, 2010$.
}

\begin{abstract}
The tasks Preferential Trade Agreements (PTAs) perform are expressed in their scope and covered issues, thus in order to be WTO compatible these aspects of PTAs should comply with the relevant WTO rules. This paper examines which aspects of PTAs can violate these rules and therefore can be challenged before the WTO Dispute Settlement Body, who may initiate such cases and why there hasn't been more cases dealing with this important issue.
\end{abstract}

Keywords: WTO, PTAs, GATT Art. XXIV, WTO Dispute Settlement

\section{Introduction}

Preferential Trade Agreements (PTAs) ${ }^{1}$ have always been an integral feature of the international trading system. But although it should be expected that they and their - most likely negative - economic effect on their parties' external trade would be a subject of multilateral concern, in fact, not only the relevant GATT/WTO rules, most importantly GATT Art. XXIV (hereinafter the Article), are imprecise, but the multilateral monitoring of states' practice in this regard is also quite lax. ${ }^{2}$ However, since only few WTO cases concern PTAs and the Article, it could be assumed that GATT/WTO members are quite satisfied with the situation and see no need to clarify the relevant WTO rules nor to verify PTAs' conformity with these rules. An example in this regard is the WTO case $E C$-Selected Customs Matters brought by the US, which was based on GATT Art. X on publication and administration of trade regulation and not the Article, which is arguably the more direct reference to the matters in that dispute. In their analyses of the case, Hoekman and Mavroidis argue that "Aside from the standard hypothesis of the 'glass house' syndrome - worries about precedent-setting and possible 'retaliation' - it is difficult to understand why these provisions were not invoked" (Hoekman et al., 2009). Commenting this explanation, Pauwelyn blames the situation on the flexibilities of the Article, which make it hard to invoke in cases and as a result final rulings would be highly unpredictable (Pauwelyn, 2009). However, like in any other international agreement, flexibilities and impre-ciseness are an integral part of the WTO. As an example, GATT Art. VI on Anti-Dumping and Countervailing Duties also includes flexibilities and imprecise formulations. But this has not stopped countries from invoking Art. VI and unlike the few

"This paper is part of the project "WTO law and EU law: Legal conflict and integration" funded by the Danish Social Science Research Council.

${ }^{1}$ Also called Regional Trade Agreements or RTAs.

${ }^{2}$ For a more detailed analyses of the Article see Lockhart et al. (2005) and Islam et al. (2009)

${ }^{3}$ The Enabling Clause has a similar function for trade-relation with and between developing countries. rulings on the Article, the panels and Appelllate Body's rulings on Art. VI have in fact clarified various aspects of it. So, why do countries seem not to be interested in clarifying the Article or monitoring its application? Why do countries not initiate more cases on the Article? And more importantly which aspects of PTAs can be in violation of the relevant WTO rules and subject of a challenge?

\section{Why PTAs?}

As it is stated in the preamble of the Marrakesh Agreement, the WTO and its agreements are "reciprocal and mutually advantageous arrangements directed to the substantial reduction of tariffs and other barriers to trade and to the elimination of discriminatory treatment in international trade relations". The general norm in this regard is the Most Favoured Nation Treatment. But as an alternative norm, the Article and its related "Understanding on the Interpretation of Article XXIV of the General Agreement on Tariffs and Trade 1994" (hereinafter the Understanding) permit WTO members to offer some members better-than-MFN treatment, if they follow some generally drafted procedures and fulfill certain criteria. ${ }^{3}$ The reason for allowing this alternative is stated in para. 4 of the Article: "The contracting parties recognize the desirability of increasing freedom of trade by the development, through voluntary agreements, of closer integration between the economies of the countries parties to such agreements. They also recognize that the purpose of a customs union or of a free-trade area should be to facilitate trade between the constituent territories and not to raise barriers to the trade of other contracting parties with such territories."

Bhagwati has suggested that historic accounts show that "few thought this exception would be used except under rare circumstances, as it was thought that having to go the whole way toward virtually free trade and extending to nearly all commodities would discourage the resort to Article XXIV" (Bhagwati, 2008). But the growing number of PTAs suggests other-wise (see Figure 1.). In fact some recent works show that the original purpose of the Article was to satisfy UK's demands for flexibil- 
ity in conducting trade with its traditional trading partners; to assist European integration; and to allow the establishment of US-Canada PTA (Chase, 2006). This suggests that the Article was not meant to restrict states' - at least the main states' - right to establish PTAs, but, as the article itself states, to allow them to shape their external trade policies and to meet their needs. In other wordsthe Article makes better sense as a political and permissive statement than as a legal and restrictive provision.

In theory and as it is officially stated, there need not to be any conflict between the WTO as the multilateral system and the PTAs. In fact, the introductory text to the WTO writes "often [PTAs] can actually support the WTO's multilateral trading system. [PTAs] have allowed groups of countries to negotiate rules and commitments that go beyond what was possible at the time multilaterally. In turn, some of these rules have paved the way for agreement in the WTO" (WTO, 2007). Nevertheless, most scholars and observers regard PTAs as a threat to multilateralism and a cause for concern (Bartels et al. 2006; Whalley, 2008).

Regardless of this discussion, and in parallel with multilateral negotiations in the WTO, many countries have been engaged in bilateral and/or regional negotiations towards establishment of PTAs (see Figure 1.). So it is safe to say that, multilateralism as embodied in the WTO has not made PTAs superfluous. Why? The answer is found in the tasks PTAs perform. In short, they fulfill states' wish to control their actions and maintain their autonomy and ability to shape their external trade policies. Many reasons can be given for this. First, it is assumed that negotiations are easier conducted among fewer countries, which in principle have common interests, than under the multilateral umbrella of the WTO where all 153 members with their very divergent interests have to agree on a result before the negotiations are concluded. Second, countries can use PTAs in a broader context: as an element in their overall economic, cultural, historical, military and/or political relations. In short, while in a multilateral setting, trade agreements concentrate on trade, in PTAs trade can be used as a mean to achieve other goals. Accordingly, they can be designed as an element of countries' overall external relations. An example of such situations is EPAs where trade is seen as a tool to further development of ACP countries. Third and the most important reason is that countries can design PTAs to cover issues that are not part of the WTO, for example investment and competition, and make more specific rules on issues that are already covered by the WTO, for example safeguard measures.

\section{Non- WTO Issues}

The WTO agreements cover those issues that the member states have been willing and able to agree upon. Thus those issues that are not covered by the WTO are in theory 'unregulated'. This is especially the case if the issues do not affect trade or are generally regarded as separate and not related to trade in goods, for example investment or competition law. In such cases, they can be included in the PTAs which are voluntary agreements between states. For example Art. 62 of the CARIFORUM EPA under its Title on Investment states that

"In pursuance of the objectives of this Title, the Parties shall enter into further negotiations on investment and trade in services no later than five years from the date of entry into force of this Agreement with the aim of enhancing the overall commitments undertaken under this Title."

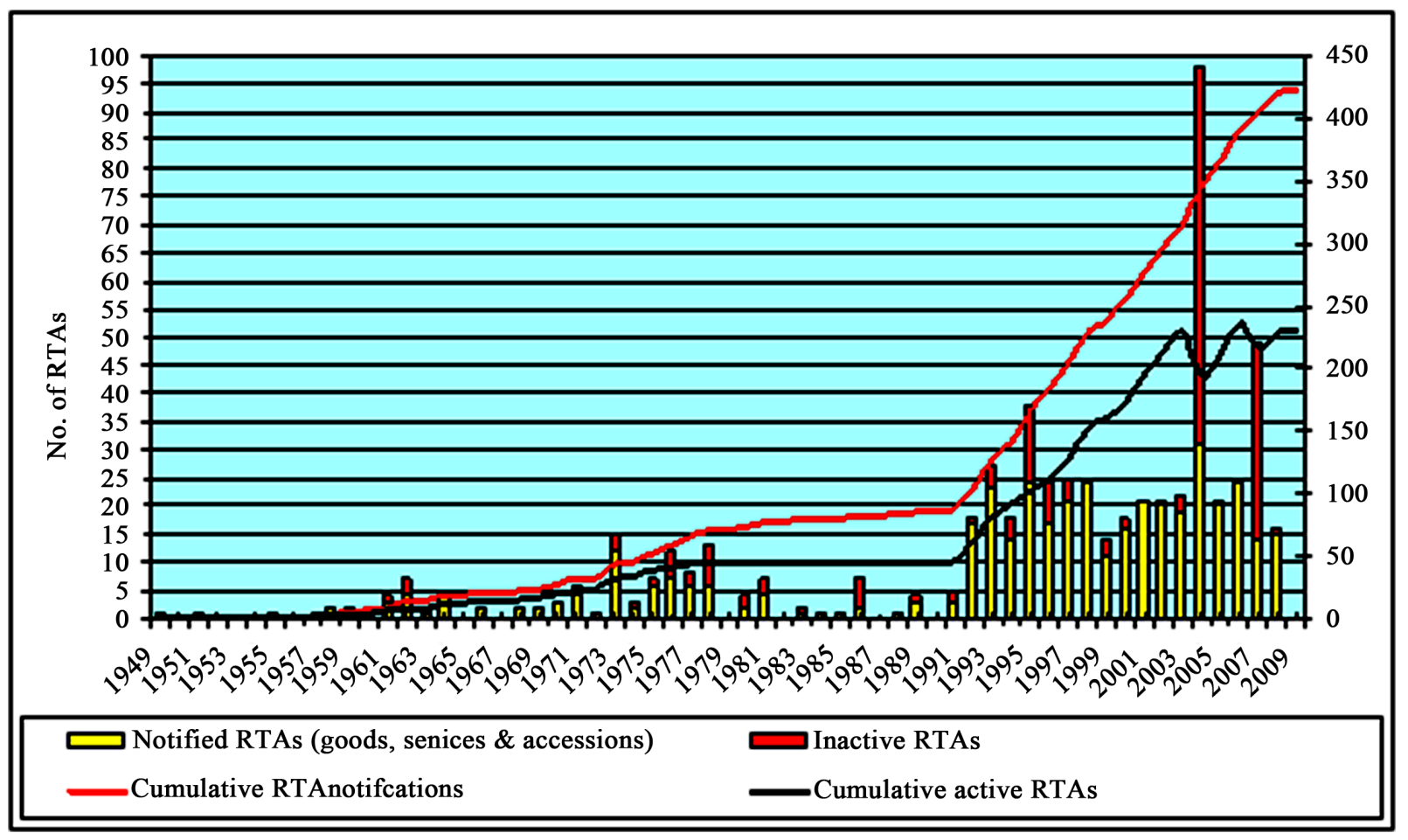

Figure 1.

Number of PTAs - Source: WTO Secretariat. 
But if the issues have direct affect on trade without being clearly covered by the WTO for example standards or concern for environment the situation is much trickier. In theory, such issues should be seen in light of the relevant WTO rules, e.g. SPS, TBT agreement or GATT Art. III or XX. But here again, since PTAs are voluntary agreements they can - and most often do - address such issues without referring to the WTO. As an example, under its Title on Tourism, Art. 116 of the CARIFORUM EPA states that:

"The Parties and the Signatory CARIFORUM States shall encourage compliance with environmental and quality standards applicable to tourism services in a reasonable and objecttive manner, without constituting unnecessary barriers to trade, and shall endeavour to facilitate the participation of the Signatory CARIFORUM States in relevant international organizations setting environmental and quality standards applicable to tourism services."

\section{WTO Issues}

PTAs also address issues that are already covered by the WTO either as specific provisions for example on anti-dumping, subsidies and safe-guards or general principles of the WTO for example dispute settlement and Most Favoured Nation rules. On the first type of issues, the relevant reference point is para. 8 of the Article, which instructs PTA signatories to eliminate "duties and other restrictive regulations of commerce (except, where necessary, those permitted under Articles XI, XII, XIII, $\mathrm{XIV}, \mathrm{XV}$ and XXX)". But the Article does not state whether the exceptions list is exclusive or not. As Gobbi and Horlick write "the absence of Articles V and XIX of the GATT in the exceptions list has raised the question of whether this provision mandates or allows abolition of trade remedies within customs unions and FTAs" (Gobbi et al. 2006). Based on the Ap- pellate Body's Ruling in Turkey - Textiles, Gobbi and Horlick argue that the list is exclusive, and accordingly at least within that portion of trade in a PTA which can be regarded as 'substantially all the trade' they are mandated to abolish safeguard and anti-dumping measures.

Against this argument, it can be stated that in ideal situations where PTAs have harmonized and removed trade barriers and cover all or at least substantially all the trade between the parties, for example in the EU, punitive duties would be unnecessary. But most PTAs are not ideal and these duties are not normal duties either. They are meant to neutralize specifically identified unfair practice of other states and exporters. Thus they cannot be compared to Art. XX or Balance of Payment situations. Nevertheless, this does not mean that such duties can be applied within PTAs. But regardless of this discussion, it is de facto up to PTA parties to decide whether such instruments should be allowed in PTAs or not and in most cases they are allowed. As an example, Art. 25.2 of the CARIFORUM EPA permits CARIFORUM states and the EU to impose safeguard measures against each other if the imported good in question "cause or threaten to cause:

(a) serious injury to the domestic industry producing like or directly competitive products in the territory of the importing Party; or

\footnotetext{
${ }^{4}$ On this topic see Sinclair (1973: 62-69).

${ }^{5}$ This development is reflected in the growing literature on the constitutional aspects of the WTO law (see e.g., Cass 2005).
}

(b) disturbances in a sector of the economy, particularly where these disturbances produce major social problems, or difficulties which could bring about serious deterioration in the economic situation of the importing Party, or

(c) disturbances in the markets of like or directly competitive agricultural products (1) or in the mechanisms regulating those markets."

Apart from more specific WTO issues, recent PTAs also address those issues that can be regarded as the general principles of the WTO law, most importantly WTO's Dispute Settlement Mechanism (DSM). As an example Art. 24.10 of the CARIFORUM EPA on safeguard measures states that "safeguard measures adopted under the provisions of this Article shall not be subject to WTO Dispute Settlement provisions." Instead it has established a 'CARIFORUM-EC Trade and Development Committee' to review such measures and issue recommendation on their legality. The question that should be asked here is whether PTAs can suspend such fundamental WTO provisions such as the DSM or not.

A rather theoretical answer to this question depends on the status of the WTO within international trade law, which brings in Art. 30 of the Vienna Convention on the Law of Treaties. ${ }^{4}$ More specifically, if the WTO is regarded as a contractual type of agreement between its signatories, then states are free to design and sign other agreements and commit themselves to both agreements. But if the WTO is seen as a type of international standard on how trade relation and regulation shall be conducted, then the signatories are bound by its provisions and cannot suspend it in subsequent treaties. The real nature of the WTO shall be found somewhere between these two poles. And although GATT started as a contract between its CONTRACTING PARTIES, it has developed to an international agreement which covers almost all countries and most of international trade, thus it is moving closer to the other pole, namely an international standard type of agreement. ${ }^{5}$

On a rather practical level the answer depends on which perspective is applied: PTA or the WTO perspective: seen from a PTA perspective, such suspension is desirable since it will limit forum shopping between the available dispute settlement organs and hereby conflicting rulings of these organs can be avoided. However, in most cases, for example NAFTA and MERCOSUR, PTA parties can choose between the WTO DSM and the PTA's own dispute settlement organ. Even in the EPAs the normal norm is that parties can chose between the two, but they cannot have simultaneous proceedings (CARIFORUM EPA Art. 222.2).

\section{What can be Challenged?}

Seen from a WTO perspective, on the other hand, DSU Art. 23 states that members 'shall' recourse to the DSM if they "seek the redress of a violation of obligation or other nullification or impairment of benefits under the covered agreements or an impediment to the attainment of any objective of the covered agreement". This article makes two points: first the conflict between the two dispute settlement organs will arise in those issues that are covered by the WTO and the PTA. And second, seen from the DSU perspective, it regards itself as the main organ. However, DSU Art. 3.1 states that members shall consider "whether actions under these procedures would be fruit- 
ful". This opens the doors for states not only to consider whether they should initiate a case, but also which forum is better equipped to settle their dispute. There is of course nothing particular about this permission, since it only confirms the normal practice of states, which not only take into account the legal merits of their case and its possible outcome, but also their available resources, and the economic aspects and political consequences of any potential case.

In any case, the conflict between the WTO and PTA is only material in situations where the issue is covered by the PTA and the WTO and if it affects non-parties to PTAs. This is because it is very unlikely that parties to PTAs will challenge PTAs' legality and their legal standing vis-à-vis the WTO. On this background, it is important to examine which aspects of PTAs can be challenged before the DSB. To answer this question it is necessary to describe the three types of PTAs and their differences. This is because although the three forms of PTAs have some common features, they differ in some central procedural and substantive aspects, which can be challenged. PTAs can be Costumes Unions (CUs), Free trade Areas (FTAs) or an Interim Agreements (IAs) leading to either a CU or a FTA.

According to para. 8 of the Article FTAs differ from CUs on two substantive accounts. First, while the constituent territories and states of a FTA are not required to establish a common external tariffs regime on goods from non-parties, members of a $\mathrm{CU}$ are required to do so. And second, while FTAs only cover trade in goods that are originated in the constituent territories, CUs may cover other goods as well.

The main differences between IAs and the other two types, on the other hand, are procedural. ${ }^{6}$ First, IAs operate with gradual elimination of duties and other restrictive regulations of commerce. ${ }^{7}$ The normal meaning of elimination is removal or getting completely rid of something, here duties and other restrictive regulations of commerce between parties to PTAs. Thus, the Article defines two ways of establishing PTAs: immediate in form of CUs and FTAs and gradual in form of IAs. But a contextual reading of the Article in light of its purpose which is stated in para. 4 indicates that CUs and FTAs need not be established immediately but have to be concluded within a shorter time than IAs. This mirrors the real world of trade policy, in which only in very few cases elimination of duties - let alone other restrictive regulations - can happen overnight and most CUs and FTAs operate with implementation periods. ${ }^{8}$

During the Uruguay Round the issue of how long transitional periods IAs can use was raised and the relevant part of para. 3 of the Understanding states 10 years as the 'reasonable length of time'. However, not only 'reasonable length of time' is an imprecise statement, para. $5 \mathrm{c}$ of the Understanding also states that in 'exceptional cases' a longer implementation period can be applied. Thus, due to lack of any instructions, it is de facto up to the parties to decide whether their situation constitutes an 'exceptional' case and if so what a reasonable length of time should be.

The second difference between IAs and the other two types

${ }^{6}$ On IAs see Bartels. (2009)

${ }^{7}$ GATT Art. XXIV.8.a.i and XXIV.8.b.

${ }^{8}$ See WTO document WT/REG/W/46 Annex 5 for a statistics on the applied transition times in the existing PTAs.

${ }^{9}$ In the WTO, the Committee on Regional Trade Agreements under

Council for Trade in Goods is the organ that shall be notified.

${ }^{10}$ See for example GATT document L/732. of PTAs is that IAs have to follow certain notification procedures which in fact amount to a ratification process. According to GATT Article XXIV.7.a, all three types of PTAs must 'promptly' be notified to the CONTRACTING PARTIES. ${ }^{9}$ Once notified, Para. 7 of the Understanding states that the PTAs "shall be examined by a working party in the light of the relevant provisions of GATT 1994 and of paragraph 1 of this Understanding. The working party shall submit a report to the Council for Trade in Goods on its findings in this regard. The Council for Trade in Goods may make such recommendations to Members as it deems appropriate". In 2006, the General Council of the WTO established the transparency mechanism for PTAs to review the notified PTAs.

If a PTA is notified as an IA, in addition to the above mentioned general assessment process, the Council for Trade in Goods also has to examine the IA's transition period and assess whether the agreement will actually result in a CU or a FTA after the period has passed. In this regard the text of GATT Article XXIV.7.b. amounts to actual approval of those IAs that are under review:

If, after having studied the plan and schedule included in an interim agreement referred to in paragraph 5 in consultation with the parties to that agreement and taking due account of the information made available in accordance with the provisions of subparagraph $(a)$, the CONTRACTING PARTIES find that such agreement is not likely to result in the formation of a customs union or of a free-trade area within the period contemplated by the parties to the agreement or that such period is not a reasonable one, the CONTRACTING PARTIES shall make recommendations to the parties to the agreement. The parties shall not maintain or put into force, as the case may be, such agreement if they are not prepared to modify it in accordance with these recommendations.

On this background, it should be stated here that states' treatment of PTAs in the GATT and the WTO has de facto removed the procedural difference between CUs, FTAs and IAs. As an example, the CARIFORUM EPA is notified as a FTA, although it operates with a transitional period of at least 10 years (see Tables 1 and 2). Furthermore, till now, none of the assessment processes has been concluded (WTO, 2006).

This can be traced back to late 1950s, when the EEC was notified to the GATT. GATT documents on the discussions between contracting parties show that the EEC notification raised many critical questions mainly regarding its timeframe and whether the formation of EEC would have negative impact on trade with non EEC-countries. ${ }^{10}$ Citing Snape, Hoekman writes, when "it was made clear by the original six EEC Member States that a GATT finding that the EEC violated Article XXIV of the GATT could well result in their withdrawal from GATT" the assessment of the EEC stopped and GATT contracting parties made a conscious political decision "not to closely scrutinize the formation of the EEC" (Hoekman et al,. 1995). As a consequence, by accepting that a full examination is not required, GATT, and now WTO members have allowed PTAs to enter into force without fulfilling all GATT requirements. The lack of any cases on the procedural aspects of PTAs supports this conclusion. However, this does not mean that the situation will remain so. As an example, CARIFORUM EPA can be challenged on two procedural grounds: first that it is not an FTA but an IA and second it has not been notified properly. But if such challenges are initiated it will necessarily question the 
Table 1.

Liberalisation schedules agreed in initialled interim agreements (cumulative value of imports from the EU, to be liberalized by the specified year). Source: http://www.acp-eu-trade.org.

\begin{tabular}{|c|c|c|c|c|c|c|c|c|c|c|}
\hline & 2008 & 2010 & 2012 & 2013 & 2017 & 2018 & 2022 & 2023 & 2033 & total \\
\hline Fiji & $24 \%$ & & & $37 \%$ & & $78 \%$ & & $81.5 \%$ & & $81.5 \%$ \\
\hline Papua New Guinea & $88.1 \%$ & & & & & & & & & $88.1 \%$ \\
\hline Comoros & & & & $21.5 \%$ & & & $80.6 \%$ & & & $80.6 \%$ \\
\hline Madagascar & & & & $37 \%$ & & & $80.7 \%$ & & & $80.7 \%$ \\
\hline Mauritius & $24.5 \%$ & & & & $53.6 \%$ & & $95.6 \%$ & & & $95.6 \%$ \\
\hline Zimbabwe & & & $45 \%$ & & & & $80 \%$ & & & $80 \%$ \\
\hline $\begin{array}{l}\text { Botswana, Lesotho, } \\
\text { Namibia, Swaziland }\end{array}$ & & $86 \%$ & & & & & & & & $86 \%+47$ tariff lines \\
\hline Mozambique & $78.5 \%$ & & & & & & & & & $80.5 \%$ \\
\hline Cameroon & & & & & & $50 \%$ & & $80 \%$ & & $80 \%$ \\
\hline Cote d'Ivoire & & & & & & $69.8 \%$ & & $80.8 \%$ & & $80.8 \%$ \\
\hline Ghana & & & & & & $62.24 \%$ & & $80.48 \%$ & & $80.48 \%$ \\
\hline
\end{tabular}

Table 2.

Liberalisation schedules agreed in initialled interim agreements (cumulative percentage of tariff lines, to be liberalized by the specified year). Source: http://www.acp-eu-trade.org.

\begin{tabular}{|c|c|c|c|c|c|c|c|c|c|c|}
\hline & 2008 & 2010 & 2013 & 2015 & 2017 & 2018 & 2022 & 2023 & 2033 & total \\
\hline Fiji & $9 \%$ a & & $22 \% \mathrm{a}$ & & & $62 \% a$ & & $80 \%$ a & & $80 \%$ a \\
\hline Papua New Guinea & $82.1 \% \mathrm{a}$ & & & & & & & & & $82.1 \%$ a \\
\hline EAC & & & & & & & & & & $74 \%$ a \\
\hline Mauritius & $26 \% \mathrm{a}$ & & & & $73 \% \mathrm{a}$ & & $96.6 \% \mathrm{a}$ & & & $96.6 \% \mathrm{a}$ \\
\hline $\begin{array}{l}\text { Botswana, Lesotho, } \\
\text { Namibia, Swaziland }\end{array}$ & & $86 \%$ a & & $44 b$ & & $3 b$ & & & & $86 \% a+47$ tariff lines \\
\hline Mozambique & & & & & & $100 \mathrm{~b}$ & & & & \\
\hline Ghana & & & & & & $72.81 \% \mathrm{a}$ & & $80.01 \% \mathrm{a}$ & & $80.01 \%$ a \\
\hline Caribbean & & & & & & & & $85.1 \% \mathrm{a}$ & $90.7 \% \mathrm{a}$ & $90.7 \% \mathbf{a}$ \\
\hline
\end{tabular}

${ }^{\mathrm{a}}$ cumulative percentage of tariff lines; ${ }^{\mathrm{b}}$ additional number of tariff lines to be liberalised by the specified year

PTA as such. Thus, it is most likely that such challenges will be regarded as last resort and will only be raised by non-parties against major PTAs.

PTAs can also be challenged based on their substantive rules. Here, the most general line of challenge will question whether PTAs as such relate to the 'substantially all the trade' requirement. But as with many other aspects of the Article, countries as well as researchers - offer different views on how this phrase shall be understood. As the Appellate Body in Turkey - Textile writes "neither the GATT CONTRACTING PARTIES nor the WTO Members have ever reached an agreement on the interpretation of the term 'substantially' in this provision. It is clear, though, that 'substantially all trade' is not the same as all the trade, and also that 'substantially all trade' is something considerably more than merely some of the trade". ${ }^{11}$

The EU has argued that 'substantially all trade' means $90 \%$

\footnotetext{
${ }^{11}$ Appellate Body Report, Turkey - Textile, para 48.

${ }^{12}$ During the EPA negotiations and in line with recommendations by most commentators, many ACP countries are in the process of defining which product groups should be exempted from reciprocal liberalization. Whether this list will be accepted by the EU, or become subject of further disagreement, time will show.

${ }^{13}$ Since the Doha negotiations are not concluded, there is no consensus on this issue.
}

of volume of trade between the parties. As an example a press-release issued by the DG-Trade on the EPAs states that "to be WTO-compatible trade agreements have to liberalise a certain minimum of trade between trading partners. The EU believes the benchmark for WTO compatibility in this case should be $100 \%$ liberalisation of EU Trade and at least $80 \%$ of ACP trade over 15 years, with the majority of this in 10 years. This represents the most generous interpretation of WTO rules ever applied - a more normal starting point would be $90 \%$ or more of trade in 10 years with no differences in the scope of liberalisation between the partners" (DG-Trade, 2007). Another example is the EU-South Africa FTA, under which the EU provides $95 \%$ of South African exports improved access to its markets, while South Africa does so for $86 \%$ of EU exports.

The remaining $10 \%$ of trade between the parties which is not covered in a PTA can, according to the EU, include whole sectors and goods, for example the EPAs do not include the EU importation of sugar and rice. ${ }^{12}$ An alternative view is stated by the US, who argues that 'substantially all trade' covers all sectors and products, leaving open the possibility of having some limits within them. The difference is that according to the US, all product groups shall be covered by a PTA, whereas the EU would exclude some products from the list. ${ }^{13}$ Regardless of this debate, there is an agreement that 'substantially all the trade' 
covers two elements: qualitative and quantitative (Lockhart et al., 2005). Qualitative element refers to the volume of trade between the parties, and quantitative element refers to number of tariff lines which are traded between the parties. Accordingly, seen in connection with the speed of liberalization under CUs/FTAs vis-à-vis IAs, it means that under IAs, countries have 10 years - or more - to liberalize a substantial number of their tariff-lines as well as the actual volume of their trade.

But, non-parties to a PTA can also base their case on para 4 of the Article if they can show that the PTA in question has harmed their trade with its PTA signatories. In this regard, in the most important case on the Article, Turkey - Textiles, the Appellate Body agreed with the panel that "an 'economic' test for assessing whether a specific customs union is compatible with Article XXIV" can be performed. ${ }^{14}$ It should be stated here 'economic test' is not a standard procedure or a recognized economic model, but presumably it is any model or test which measures the economic impact of a PTA or its specific rules on trade with non-parties. Whether the test shall include the whole volume of the trade, or can be done on a single product is not clear. But in the case of former, the dispute will question the $\mathrm{CU}$ as such, while in the latter case, the issue at hand will be on specific duties or regulatory measures on the addressed products. It should also be stated that since FTAs do not operate with same external tariffs, as CUs do, the test cannot be based on volume of trade with FTAs as a whole, but with each single FTA party.

Potential cases can also be based on para. 5 of the Article which states that "the provisions of this Agreement shall not prevent ... the formation of a [PTA]; Provided that" CUs' duties and other regulations of commerce with non-parties "shall not on the whole be higher or more restrictive than the general incidence of the duties and regulations of commerce applicable in the constituent territories prior to the formation of such [PTAs]". And in the case of FTAs and IAs leading to formation of FTAs, para.5b states that the duties and other regulations of commerce with non-parties imposed at the institution of the FTAs "shall not be higher or more restrictive than the corresponding duties and other regulations of commerce existing in the same constituent territories prior to the formation of the free-trade area, or interim agreement as the case may be". Accordingly, PTAs can be challenged on one main issue: higher or more restrictive 'duties and other regulations of commerce' upon their institution. Whether this is the case depends on which type of PTAs the agreement is. Accordingly, in the case of CUs para. 2 of the Understanding states that the evaluation should be based on "an overall assessment of weighted average tariff rates and of customs duties collected".

In the case of FTAs it is a direct comparison of duties and other regulation before and after the establishment of FTAs. Thus it is easier to use the article against FTAs. Nevertheless, in Turkey - Textiles case, para. 5 was used as a defense and regarding a CU. The final ruling in the case found that as an exception, the Article can be used as a defense and its success can be assessed by a 'necessity test'. According to this test

\footnotetext{
${ }^{14}$ WTO Appellate Body Report, Turkey - Textile WT/DS/AB/R, adopted 21 March 1996, para 55.

${ }^{15}$ Appellate Body Report on Turkey - Textiles, para. 46.

${ }^{16}$ WTO Appellate Body Report, Argentina - Footwear, WT/DS121/AB/

R, adopted 6 April 1998, para. 114.
}

"Article XXIV can justify the adoption of a measure which is inconsistent with certain other GATT provisions only if the measure is introduced upon the formation of a customs union, and only to the extent that the formation of the customs union would be prevented if the introduction of the measure were not allowed." 15

Non-parties can also challenge specific practice of PTAs and their members. In this regard an example is given in Argentina - Footwear on the application of safeguard measures within a CU. Here, Appellate Body writes:

"We conclude that Argentina, on the facts of this case, cannot justify the imposition of its safeguard measures only on non-MERCOSUR third country sources of supply on the basis of an investigation that found serious injury or threat thereof caused by imports from all sources, including imports from other MERCOSUR member States. However, as we have stated, we do not agree that the Panel was dealing, on the facts of this case, with a safeguard measure applied by a customs union on behalf of a member State. And we wish to underscore that, as the issue is not raised in this appeal, we make no ruling on whether, as a general principle, a member of a customs union can exclude other members of that customs union from the application of a safeguard measure." $" 16$

Similar rulings are issued in United States - Line Pipe and most recently in Brazil - Retreaded Tyres.

Finally, PTA parties' actions can also be challenged by themselves, if they violate their WTO obligation, for example in relation with anti-dumping or subsidy measures. This relates back to our discussion above on whether PTAs can suspend their parties' WTO obligations. Thus it is important to monitor such provisions.

\section{Conclusion}

The underlying puzzle this paper aimed to address is the relation between PTAs and the WTO. In this regard, it can be asked why there has not been more cases questioning the PTAs' compatibility with the WTO. Two answers were given in the first section, namely, the so called 'glashouse effect' and the rules' flexible nature. Furthermore, the above analyses showed two more reasons. First, PTAs can in fact be challenged on three fronts: multilateral: during the notification/assessment process, bi- or plurilateral: between interested parties and PTA parties; and finally before the DSB. In other words, state practice and the Article's ambiguities are not the only reasons why there has not been more cases. If WTO members find a reason to complain against a PTA, they do not necessarily need to bring a case before the DSB. They can use the assessment process as a common judiciary forum. The problem here is that it is not a neutral and legalized organ as the DSB, but a political negotiations forum. And as such it lacks the exact instruction on how the assessment process should proceed. In this regard, the newly established Transparency Mechanism can provide the institutional support to a stronger review of the PTAs. But knowing that the assessment process can generate important information, which can be used by the WTO members to modify PTAs or neutralize their negative impact, it should be more specific and detailed. In particular, the assessment process should examine those aspects of PTAs which can be regarded as suspension of parties' WTO obligations, most importantly 
PTAs' dispute settlement procedures, and those non-WTO issues that have an impact on the parties' internal and external trade.

This brings us to the second reason for the inactivity of the WTO's DSM. Namely, in many cases either de jure and/or the facto PTAs prohibit their parties to use the DSM. As it was showed above, it is not clear whether such suspensions are permitted or not. But not only the very states who can ask for a clarification are prohibited from doing so but they have also voluntarily signed to PTAs. Thus, it is highly unlikely that an answer will ever be given to this question. Having said that, small and less-powerful states are not fully able to resist pressure from more powerful states. In such situations, powerful states are in a better position to determine which issues should be covered by PTAs and how deep PTAs shall be without meeting meaningful resistance from their less powerful partners who in many cases are dependent on aid from their powerful partners and/or need access to their markets. Multilateral rules, institutions and stronger monitoring of PTAs could in this regard neutralize the power asymmetry between the negotiating parties. In fact although the current WTO provisions are quite flexible, they establish standard for notification, review and approval of the PTAs, which are unfortunately not always followed.

\section{References}

Bartels, L. (2009). Interim agreements under Article XXIV GATT. World Trade Review. 8(02). 339-350.

Bartels, L. \& Ortino F., Eds. (2006). Regional Trade Agreements and the WTO Legal System. New York, Oxford University Press.

Bhagwati, J. (2008). Termites in the Trading System: How Preferential Agreements Undermine Free Trade. Oxford, Oxford University Press.

Cass, D. Z. (2005). The Constitutionalization of the World Trade Or- ganization: Legitimacy, Democracy, and Community in the International Trading System. New York, Oxford University Press.

Chase, K. (2006). "Multilateralism Compromised: The Mysterious Origins of GATT Article XXIV." World Trade Review 5(01): 1-30.

DG-Trade (2008). Interim Economic Partnership Agreements: Questions and Answers. Communique issued by European Commission, External Trade, 27.

Gobbi, A. T. \& Horlick, G. N. (2006). Mandatory Abolition of Anti-Dumping, Countervailing Duties and Safeguards in Customs Unions and Free Trade Areas Constituted between WTO Members: Revisiting a Long-standing Discussion in Light of the Appellate Body's Turkey - Textiles Ruling. Regional Trade Agreements and the WTO Legal System. L. Bartels and F. Ortino. New York, Oxford University Press: 109-148.

Hoekman, B. M. \& Kostecki, M. M. (1995). The Political Economy of the World Trading System: From GATT to WTO. Oxford; New York, Oxford University Press.

Hoekman, B. M. \& Mavroidis, P. C. (2009). Nothing dramatic (... regarding administration of customs laws). World Trade Review. 8 (Special Issue 01). 31-44.

Islam, M. R. \& Alam, S. (2009). Preferential trade agreements and the scope of GATT article XXIV, GATS article V and the enabling clause: An appraisal of GATT/WTO jurisprudence. Netherlands Inernational Law Review. 56(01). 1-34.

Lockhart, N. J. S. \& Mitchell, A. D. (2005). Regional Trade Agreements under GATT 1994: An Exception and Its Limits. Challenges and Prospects for the WTO. A. D. Mitchell. London, Cameron May.

Pauwelyn, J. (2009). Nothing dramatic (... regarding administration of customs laws). World Trade Review 8(Special Issue 01). 45-48.

Sinclair, I. M. (1973). The Vienna Convention on the Law of Treaties. Manchester, Manchester University Press.

Whalley, J. (2008). Recent Regional Agreements: Why so many, why coming so fast, and where are they headed? The World Economy. 31(4). 517-532.

WTO. (2006). Work of the Committee on Regional Trade Agreements (CRTA). Retrieved 15/4, 2008, from http://www.wto.org/english /tratop_e/region_e/regcom_e.htm.

WTO (2007). Understanding the WTO. Geneva, World Trade Organization. 